\title{
Equality in Canada: A tale of non-normative groups struggling with grounds of discrimination
}

\author{
OÑAti SOCiO-Legal Series Volume 10, Issue 1 (2020), 88-122: The Policy Of Cultural RightS: \\ StATE REgUlATION, SOCIAL CONTESTATION AND CULTURAL DiVERSITY \\ DOI LINK: HTTPS://DOI.ORG/10.35295/OSLS.IISL/0000-0000-0000-1066 \\ RECEIVED 28 NOVEMBER 2018, ACCEPTED 15 JULY 2019
}

\section{NAUSiCA PALAZZO* (iD}

\section{Abstract}

This article intends to address the limits associated with a rigid grounds-based approach to equality, requiring claimants to categorize their identity within an enumerated ground to "deserve" the protection of the equality guarantee. To this end, I first shed light on the irreconcilability of rigid grounds with post-structuralist accounts of identity, and then lay claim to an approach to equality that extends its reach to fluid, intersectional groups. Thereafter, taking Canada as a case study, I parse out the Canadian equality jurisprudence, particularly the cases offering an analysis of the aforementioned grounds. I then move to sketch out two proposals to overcome the risks associated with the current equality jurisprudence, by focusing on marital status discrimination. I ultimately offer a cursory overview of the complex interplay between approaches to equality and the organization of interest groups, and illustrate the issues around the organization of "post-identity groups".

\section{Key words}

Grounds; equality; discrimination; families; Canada

\section{Resumen}

Este artículo se propone abordar los límites relacionados con un enfoque de la igualdad rígido y basado en motivos de discriminación (grounds), exigiendo que los demandantes categoricen su identidad como un motivo enumerado para "merecer" la tutela de la garantía de igualdad. En primer lugar, arrojo luz sobre la irreconciliabilidad de los motivos rígidos con concepciones posestructuralistas de la identidad, y después

\footnotetext{
* Nausica Palazzo holds a cum laude Ph.D. in Comparative Constitutional Law at the University of Trento. She is a postdoctoral researcher at the University of Trento and Fondazione Bruno Kessler and Adjunct Lecturer in Public Law at Bocconi University, Milan. She trains public bodies on anti-corruption law through Transparency International Italia, worked as a lawyer, and conducted research a Fulbright Fellow at the University of Michigan, Ann Arbor. She published both in Italian and English on subjects related to Antidiscrimination Law, Comparative Constitutional Law, and Voting Rights. Contact details: Bocconi University, Via Roentgen 1, Milan (MI), 20138, Italy. Email address: Nausica.palazzo@unibocconi.it
} 
propongo un enfoque de la igualdad extensivo a grupos fluidos e interseccionales. Analizo la jurisprudencia canadiense sobre igualdad, sobre todo los casos que ofrecen un análisis de motivos. En ese punto, esbozo dos propuestas para superar los riesgos asociados a la jurisprudencia actual sobre igualdad, centrándome en la discriminación por estado civil. Por último, ofrezco un somero repaso de la compleja interacción entre los abordajes de la igualdad y la organización de los grupos de interés, e ilustro los problemas que acechan a la organización de "grupos posidentitarios".

\section{Palabras clave}

Motivos de discriminación; igualdad; discriminación; familias; Canadá 


\section{Table of contents}

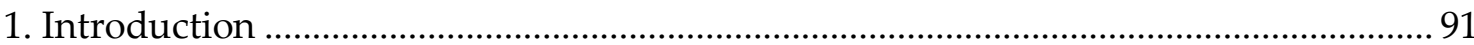

2. The problem with grounds and the vision of equality they foster............................... 93

2.1. The conception of "equality" underlying s. 15 ...................................................97

3. The Canadian model of constitutional review vis-à-vis discrimination ....................... 99

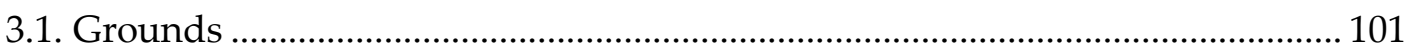

4. "Grounding" equality in the Constitution: Addressing old and new forms of

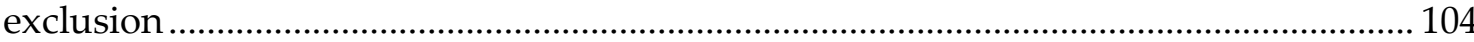

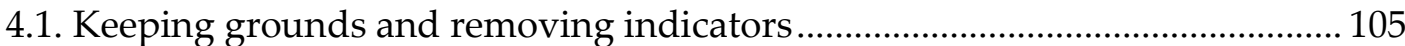

4.2. Keeping status and much less stringent indicators ........................................... 109

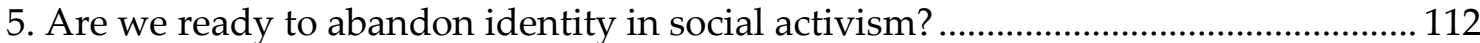

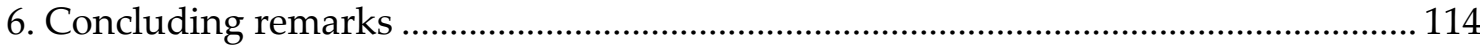

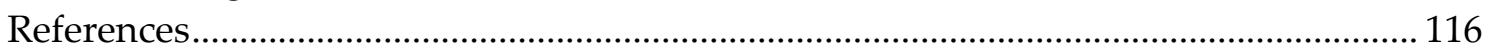

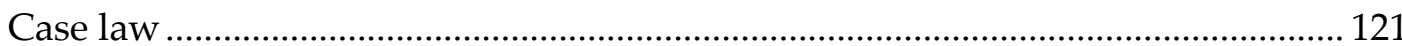




\section{Introduction}

The subheading of this Article, A tale of non-normative groups struggling with grounds of discrimination, preludes the limits of a rigid grounds-based (or categorical) approach to equality. By non-normative groups I refer to those groups of persons unable to identify with a category which is protected under the domestic equality clause. Many groups nowadays can hardly be shoehorned into the most common grounds for discrimination that Western jurisdictions tend to protect at various levels, be they constitutional, quasiconstitutional or legislative (such as race, sex, marital status, sexual orientation, etc.). When taking fixed categories as the benchmark, many groups turn out to be intersectional, fluid and non-normative in the sense that they do not comply with the essentialist vision of identity grounds of discrimination convey. In this sense, the Article is concerned with the marginalization that group outcasts and minorities within larger groups would endure, should they consistently be precluded from invoking the protection of the equality guarantee.

The problem arises in jurisdictions adopting a grounds-based or categorical antidiscrimination approach to equality. This approach differs from so-called "equality approaches" that several civil law jurisdictions in Europe adopt (such as Germany and Italy). The latter systems pivot on a conception of equality as rationality (meaning that, save when an adequate justification is put forward, like cases must be treated alike and different cases must be treated reasonably differently). In addition, they adopt substantive (or de facto) equality provisions, placing upon the state an obligation to actively promote equality, either for all individuals or for specific groups. Pursuant to this conception, equality acts as a "self-standing principle of general application". ${ }^{1}$

By contrast, anti-discrimination approaches to equality are especially widespread in common law jurisdictions and meta-national systems in Europe (the European Union and the European Convention of Human Rights framework). I will focus on a sub-set of anti-discrimination approaches to equality, namely those approaches protecting against discrimination based on a fixed or open list of grounds (so called grounds-based or categorical approaches to equality). When such an approach is adopted, as in Canada, equality becomes "no more than protection from discrimination on specific grounds" (Iyer 1993, p. 180), i.e. based on categories that capture characteristics that a person has or is perceived to have.

In addressing the dangers associated with a categorical approach to equality, I was aware I was taking on a tall task, and thus made some methodological decisions to significantly narrow the scope of the research. First, as to the geographic scope, I took only Canada as a case study. Within the multi-layered system of protection against discrimination, I focused on constitutional litigation, with a special emphasis on the equality jurisprudence that shapes the concept of "grounds of discrimination". Ultimately, within this articulated jurisprudence, I took marital status discrimination as a case study, since I believe it epitomizes the risks associated with a categorical approach to equality.

1 One must be alert that the principle is so deeply-rooted in European continental systems that often, even when the constitution includes grounds, the prevailing conception is one pivoting on equality as a principle of general application. 
Several factors pushed me to believe that Canada is a privileged site of investigation. The most vivid academic debate as to whether grounds are beneficial or detrimental to achieving equality took place in Canada, especially in the 1990s and in the early 2000s. Furthermore, the equality jurisprudence has been the site of heated debate, due to the non-linear equality test the Court outlined over the span of thirty years (Ryder 2013). In addition, a rich debate as to whether grounds were actually fostering equality took place.

The decision to focus on constitutional litigation is far from unproblematic. I am aware that there are other jurisdictional forums to shield individuals from discrimination. Reference is made especially to the human rights tribunals which were established to enforce the federal and provincial human rights codes. These tribunals proved extremely successful in disentangling inequalities in many areas. I am especially conscientious about the issue of the venue since in the last few years I was criticized for overrating constitutional litigation, compared to the litigation under the human rights codes, which was the one "doing the job". Then, I was criticized for overrating human rights tribunals, as they were far less responsive in practice and were by no means replacing nor necessarily contributing to a decreased incidence of constitutional litigation in the field of equality.

Yet, one should note that human rights codes also adopt a grounds-based approach to discrimination, by merely prohibiting discrimination based on fixed grounds (although the list of grounds is longer and more articulated, and the doctrine more settled compared to the constitutional level). Hence, for purposes of this analysis, the current debate between those maintaining that the Canadian Charter of Rights and Freedoms has actually brought change to the legal system and those arguing that change was already underway is relatively irrelevant (Hameed and Simmonds 2008, p. 181, Young 2011, pp. 317-336). Since both forums adopt a grounds-based approach to discrimination, I will address constitutional litigation as a case study, without siding with any of the two factions in this important debate.

As to "why marital status?", in recent years, the misalignment between the current categorical approach to equality and the host of groups unable to dovetail with relevant categories has become particularly dramatic in the field of family law. Non-traditional relationships are flourishing everywhere (or at least becoming more visible). These relationships include, but are not limited to, siblings, friends, relatives, unmarried conjugal couples, queer assemblies, and polyamorous relationships. This is to say that the number of group outcasts is high in the context of marital status discrimination, compared to the number of group outcasts in other domains.

A cutting-edge academic debate took place over the issue of the misalignment, comprising of various institutional reports pushing for a broader understanding of family, especially one disentangled from conjugality (British Columbia Law Institute 1998, Law Commission of Canada 2001).

Moreover, Canadian demographics are unique. They reveal a marked trend towards the pluralization of family arrangements. For instance, the rise of de facto couples is especially visible in Quebec (Le Bourdais and Lapierre-Adamcyk 2008, p. 80), a constant decline of marriage has been noted nationwide (Payne and Payne 2015, p. 2 ff), multigenerational families are the "fastest-growing household type since $2001(+38 \%)$ " (Battams 2018), and, ultimately, based on a survey conducted by the Vanier Institute (yet 
on a limited number of 517 respondents), almost two thirds of respondents were in a self-proclaimed polyamorous relationship, and the remaining third alleged that it was involved in some way in a polyamorous relationship in the last five years (Boyd 2017, p. 3).

For all the reasons stated above, I think Canada is the ideal site of investigation and I intend to draw on its rich scholarship and equality jurisprudence at the constitutional level to argue for the inadequacy of a categorical approach to equality.

In the first part of the article (Section 2), I will outline the problems grounds of discrimination pose, by drawing on a copious array of contributions by post-structuralist and critical legal theorists. I will thereby attempt to assess which vision of equality a rigid grounds-based approach seeks to foster and contrast it with an alternative vision focused the redistributive dimension of substantive equality.

Then, in Section 3, I will expound the Canadian model of constitutional review vis-à-vis discrimination, and offer a primer of the (unsettled) equality test laid out by the Supreme Court. While the equality test is only sketched out, I will explore more in detail the strand of jurisprudence dealing with the notion of enumerated and analogous grounds of discrimination, as this is the primary focus of the paper.

Section 4, titled Grounding equality at the constitutional level: Addressing old and new forms of exclusion, acknowledging the problems associated with a "typical" s. 15 pleading, and with employing static grounds, attempts to propose two viable routes to foster a more inclusive and redistribution-oriented notion of equality in the context of marital status discrimination. The two routes I identify to promote such a notion of equality in the field of family law are: (1) Keeping grounds and getting rid of indicators; and (2) Keeping grounds and setting forth much less stringent indicators.

Thus, I fall short of arguing that one should eliminate grounds altogether, while I offer two approaches that significantly alter their current function, that of screening out claims, by providing a more liberal and large interpretation of grounds in the field of marital status. Ultimately, in Section 5, I briefly explore the dynamic interplay between approaches to equality and social activism, to predict some of the challenges a new model of social activism that is based on "interest" rather than "identity" could pose to equality law, and vice-versa how the proposed changes to anti-discrimination legal frameworks would impact the organization of interest groups.

\section{The problem with grounds and the vision of equality they foster}

What current grounds-based approaches to equality tend to obscure is the complex way in which categories are built and the contingent assertion of power that lays behind categorizations. While grounds are understood as neutral categories that assist us in putting things in the right place, they are by no means neutral.

The contribution that post-structuralist theory gave in this regard is invaluable. Queer theorists described identity as a set of multiple and unstable positions, by arguing that categorizations under one of any such components is arbitrary and deceptive. Such a point sheds light on the inadequacy of categorizations based on a single position (e.g., sexual orientation), for they do not offer an adequate account of the matrix of identities one can present. With its rejection of a status and a priori attributes, queer theory echoes 
those notions that are free-floating (from any substrate) and provides an understanding of identity as something which is not connected to an essence but to a performance (Taylor 1993). The limited heuristic and descriptive value of static identities and fixed grounds has been exposed by post-structuralist theories in every domain. ${ }^{2}$ The common thread is that these allegedly fixed categories entrench an essentialist (whether pure or strategic) notion of identity, which obscures the reality of one's complex identity(ies).

Essentialism risks further marginalizing social outcasts, unable to align with existing categories. Group outcasts are disadvantaged twice. First, when the role of the categorizer is regarded as neutral, without acknowledging the background norms reflecting the dominant social identity against which categorizations are made. On one side, this explains why distinctions based on sex are regarded as invidious while those based on intelligence quotient are not (Iyer 1993, pp. 186-87). On the other, it clarifies why an equality claim will not be successful unless "the claimant's experience of discrimination can be made to accord with how the dominant group imagines discrimination on the basis of a given characteristic" (Iyer 1993, p. 193).

Second, they are discriminated against once categories are established, since, for categorizations to be successful, inter-group differences should be emphasized and intra-group differences downplayed, if not suppressed. Assignments of difference always obscure other aspects of one's social identity and some similarities and differences between the comparative elements. In this sense, once categories are established, there is an ever-present risk of "reducing groups to congealed caricatures that constrain individual lives" (Sheppard 2001, p. 916). That is, there is an ever-present risk of essentialism.

Categories also entail hierarchy, since assignments of difference are assertions of power. ${ }^{3}$ In turn, an authoritative decision as to what a category is yields immediate effects on the societal perception of what is normal and appropriate in a given context. Any decision excluding non-normative families from the category "marital status" or "family status" sends clear messages pertaining to the way family relationships should look like. Thus, the role of the categorizer is by no means neutral and always entails an assertion of power that has a tremendous impact on society, which regards that categorization as an expression of a pre-given state of affairs which is "described" rather than actively "constituted".

Grounds are dangerous in another sense. They have been criticized for reifying groups and ossifying an ever-shifting reality. Prof. Leckey argues that a thus-framed equality analysis yields constitutive effects on identities (Leckey 2007, p. 79). The effect is only intensified by a recognition that once recognized analogous groups are permanently included in the list of protected grounds. Such a recognition produces undesirable effects in the field of family law, for instance on unmarried conjugal couples, since "[t]he idea that substantive distinctions between married and unmarried couples may well be discriminatory and offensive to the human dignity of unmarried couples complicates the rehabilitation of unmarried cohabitation as an alternative family form valuable for its distinctness from marriage" (Leckey 2007, p. 80). The delimitation of common law

\footnotetext{
2 For race see Appiah 1992, for gender see Butler 1990, for sexual orientation see Kosofsky Sedgwick 1990.

${ }^{3}$ For a discussion in the field of sex where maleness is regarded as the benchmark, and femaleness as the difference, see MacKinnon 1987, p. 34.
} 
couples as an identity groups thus curtails social acceptance of these couples and prevents an adjustment of the competitive normative orders that characterize current family patterns (Leckey 2007, p. 80).

The use of grounds in turn affects the notion of equality that a jurisdiction fosters. Under a categorical approach, equality is not for all but just from "some". The equality promise only applies to those categories deemed worthy of protection. This limited understanding of equality, as a consequence, has eclipsed what should be, according the Prof. Fineman, the ultimate aspiration of a just society: eliminating social, economic, and political inequalities that exist across groups (Fineman 2008, p. 4).

Yet, this is likely to be seen as an apodictic claim unless one clarifies what the alternative visions of equality are and what the theory of justice suggesting valuing one vision over the others is. First, comes formal equality, which in a nutshell requires that "likes should be treated alike". While popular in the 18th century for historical reasons (concerning the particularization and division in social layers peculiar to societies predating the late modern era), the imposition of sameness of treatment is now largely seen as an insufficient tool for addressing the deep economic, social, and political imbalances in our societies. Such imbalances are better addressed if equality is considered as requiring more than sameness, i.e. equitable outcomes or opportunities for all.

This second version of equality is called substantive equality. Yet, one could hardly come to an agreement as to what substantive equality means. I concur with Fredman (2011, p. 25) that substantive equality is a four-dimensional concept (potentially aiming at redistribution, recognition, transformation, and participation). If one accepts the dualist perspective proposed by Nancy Fraser (according to which cultural and economic injustices can be dealt with separately), recognition addresses cultural harms, while redistribution addresses economic injustice or "disadvantage" (Fraser and Honneth 2003, pp. 7-9). The transformative dimension seeks to fix the detriment attached to difference, while at the same time keeping and accommodating difference. This dimension posits that due to the worse treatment some groups receive by reason of their difference, structural changes should be made to accommodate their special needs (Fredman 2011, p. 30). Ultimately, the participative dimension, requires that all persons are enabled to fully participate in the political process, and in their community and society in general.

I contend that struggles for recognition and redistribution are at odds only if they are both understood "narrowly". First, an obvious tension between the two exists if recognition is understood as an endeavor to demarcate some identities in opposition to others, i.e. if combined with identity politics. If this kind of demarcation occurs, the struggle of non-normative families for redistribution will be at odds with the struggle for recognition of same-sex couples' identity (Palazzo 2018). By contrast, reconciling the two is not only possible but necessary if one understands recognition harms as those aimed at preventing people from being devalued in society, by pivoting on the fundamental concept of human dignity. The latter view was put forward by L'HeureuxDubé J in Egan v Canada [1995] 2 SCR 513, par. 39 [Egan], where she emphasized a need to ensure that all individuals are treated as equally deserving concern, respect, and consideration. 
Under a framework mostly compatible with L'Heureux-Dubé J theory of equality, recognition is only relevant to the extent it aims at addressing the feeling of inferiority or rejection suffered by a vulnerable group. My contention is that this view is compatible with those seeing redistribution as the primary goal of equality. Let me provide an example: two cohabiting committed relatives seeking to obtain legal benefits primarily aim at fixing the economic injustice associated with the invisibility in the eyes of the law of their relationship (while they fall short of defending a "cultural identity" and the symbolic recognition thereof). Access to the material benefits will collaterally fix the feeling of disrespect non-recognition engenders in them. By contrast, in Western societies same-sex couples deliberately chose to focus their litigation strategy on the symbolic harms of non-recognition, while welcoming redistribution as the natural consequence of official recognition.

Redistribution must not be read narrowly either. Disadvantage is more than mere misallocation of material goods. The theories of justices focusing on this narrow reading of "redistribution" overlook the broadest picture: the constraints structures of domination impose on people as a consequence of their positioning in society (Young 1990).

In the end, the combination of a (L'Heureux-Dubé-like) purposive human dignity approach to recognition with redistribution as a struggle against structures of domination provides a useful "theory of justice", if one wants, to reach a more inclusive notion of equality that aligns with post-structuralist theories. This notion of equality "is result-oriented and takes into account past circumstances and future obligations, considering need and disadvantage" (Fineman 2008, p. 4). It differs from the transformative dimension of substantive equality that, as it will be seen, Canadian courts adopt, in that it is not so much concerned with accommodating differences, as it is with reaching redistributive justice (Froc 2011).

Such an approach aims at accounting for the vulnerability experienced by a set of individuals left out of "privilege and favor conferred on limited segments of the population by the state and broader society through their institutions" (Fineman 2008, p. 1). It is a post-identity paradigm in the sense that it is not so much concerned with the notion of identity group, but with distributive justice, i.e. with the actual distribution of resources carried out by the state and society through public institutions and the substantive outcomes of such distribution (Fineman 2008).

The question then arises as to how this theory interacts with legal approaches to equality. First, like transformation, redistribution is intrinsically asymmetrical in that it does not focus on an abstract identity, but rather on the sub-group within the broader category which has most suffered from disadvantageous treatment. Categories tend to be both under-inclusive and over-inclusive in some respect, as they inevitably exclude marginalized people unable to align with them, and include a sub-set of people that are not suffering from relative disadvantage. The latter problem is epitomized by the symmetrical application of most grounds. A symmetrical application of the ground of sex, for instance, will include under the protection of the equality guarantee both men and women, despite men lacking a history of disadvantage.

Second, grounds-based approaches to equality, as applied in Western societies, leave undisturbed the broadest systemic inequalities that disadvantage some members of 
society compared to others and intact the material, cultural and social inequalities in our social compact. An approach aimed at distributive justice would not suffer from this shortcoming.

These two aspects intertwine. Grounds-based anti-discrimination systems produce several anomalies. Chief amongst them is the possibility that a person can exploit past disadvantage or incidental inclusion in a category to claim equality and "excel, even triumph in a "white men's world'" (Fineman 2008, p. 16). By contrast, an approach attentive to real-life experiences could severely reduce the occurrence of such anomalous outcomes, by redirecting focus onto the way in which asset-conferring institutions and laws privilege some and exclude others.

This point leads to the conclusion that the ideal target of equality should not be an identity-based group but rather vulnerable groups gathering the "vulnerable subject" (Mackenzie et al. 2014). Vulnerability is a notoriously hazy concept, and as such it has been used inconsistently in socio-legal literature (Bridgeman 2013). A first understanding sees it as a condition embedded in the destiny of all human kind. In this sense, it has a pivotal role in the context of post-identity theories, attempting to transcend fixed groups as the target to detect inequalities. This concept of vulnerability is genuinely universal, in that it concerns the possibility for all persons to be affected by events that are beyond human control (such as bodily harm, disease, natural disasters, etc.). Since it is embedded in human destiny, and cannot be deemed to be a distinctive feature of a single group, such a notion of vulnerability would be prima facie incompatible with any discrimination claim. However, a second understanding stresses that higher vulnerability can be experienced by specific, situated, individuals, who are somehow left out from privileges and who lack material resources, due to their positioning in a network of institutional and economic institutions (Fineman 2008, p. 10, Herring 2015, p. 2). This notion of vulnerability is more inclined to account for people's lives, relational experiences and distribution of advantages and disadvantages. However, the first meaning should necessarily inform the second one, if one wants to avoid circling back to a state of things where populations are ordered hierarchically with the liberal, rational, self-sufficient subject put on top, and the vulnerable (inferior) subject put at the bottom and turned into a "non-subject" (think about elderly people of individuals lacking legal capacity) (Fineman 2012, p. 86).

Thus, vulnerable groups, as defined above, should be the privileged beneficiaries of equality law.

\subsection{The conception of "equality" underlying s. 15}

With the advent of the Canadian Charter of Rights and Freedoms of 1982, Canada enacted a far-reaching system of rights protection that gained constant attention at the global level. The country has indeed adopted original legal solutions in the field of equality law. These solutions have circulated widely in foreign superior courts, and have occasionally been transplanted to other legal systems, such as South Africa. In its first years, section 15 of the Charter (i.e., the equality clause) acted as a powerful catalyst in bringing the law in line with the revolutionary equality principles enshrined in the Charter. It did so not only by allowing judges to strike down all laws inconsistent with the (from time to time broad) interpretation of the equality clause, but also by permeating the legal culture and the approach of jurists, judges, clerks and policy- 
makers in developing, each in their capacity, the law. ${ }^{4}$ Framers were well aware of the over-reaching potential of this section, when they delayed its entry into force to 1985 (three years after the enactment of the Charter), with a view to making the transition "smoother".

On a less positive note, there are several aspects that suggest for a much more cautious optimism in analyzing the potential of s. 15 to disentangle inequality. Many noted that the section promised much more than it could deliver. For a start, equality is an "elusive concept", and as a consequence s. 15 is one of "Charter's the most conceptually difficult provisions" (Law v Canada (Minister of Employment and Immigration), [1999] 1 SCR 497) [Law].

In attempting to grapple with the concept, the Supreme Court has adopted an increasingly formalistic approach to its construction. Under the Canadian equality jurisprudence, substantive equality entails equality of opportunity and results (L'Heureux-Dubé 2002, p. 368) and presents a "large remedial component" (Andrews v Law Society of British Columbia, [1989] 1 SCR 143) [Andrews]. It differs from formal equality in that it entails a purposive approach requiring a proper account of "difference" and that disadvantaged group be granted special treatment to improve their situation (transformative dimension). This vision of equality tends to focus on difference and the different treatment that is warranted to accommodate the special needs of some groups (the key example being positive measures to combat inequalities). Yet, the reluctance to deliver this version of equality has been widely criticized in legal scholarship (McIntyre and Rodgers 2006, Faraday et al. 2006, Young 2010). Nonetheless, the Court continues to emphasize its firm commitment to achieving (this type of) substantive equality.

By contrast, what seems to be largely missing in the quality jurisprudence is the redistributive dimension of substantive equality. Courts have been wary to inject redistributive justice into the system. Grounds are but one of the reasons for this failure. The mentioned dangers associated with a grounds-based approach to equality must be analyzed in conjunction with the liberal understanding of constitutionalism informing the Charter. Pursuant to this understanding, claims aimed at gaining affirmative entitlements face the limit of the general non-justiciability of affirmative rights (i.e., requiring state intervention for them to be fulfilled) under the constitution (Jackman and Porter 2014). In the context of equality rights, the explicit characterization of s. 15 as a negative protection ( $R . v$ Kapp, [2008] 2 SCR 483, para. 16) [Kapp], is something that weighs heavily with the likelihood of success of equality claims that aim to expand under-inclusive programs.

This doctrine could be detrimental to non-normative families seeking to obtain new public benefits, while they are hardly applicable with respect to private family law benefits, such as spousal or child support. The latter cohort of benefits raise wholly different issues, concerning adherence or otherwise to neo-liberal attempts at privatizing care, by shifting the burden of such care on private individuals rather than the state (Cossman and Fudge 2002).

\footnotetext{
${ }^{4}$ L'Heureux-Dubé 2002. But see Arthurs and Arnold 2005, providing an account of the Charter failure to address inequality and positively impact Canadian political economy.
} 
As to public benefits, for instance, Prof. Wiseman noted that "when governments have chosen to use legal measures to improve substantive equality, constitutional law has generally facilitated that choice by upholding the constitutionality of these legal measures". By contrast, when attempts were made to compel governments to advance social justice through new programs or an expansion of existing ones, the Court fell short of acting and deferred to the discretion of legislatures (Wiseman 2015, p. 565). This merely "facilitative" role of constitutional justice is thus of little help anytime a claim aims at compelling governments to actively promote substantive equality, by introducing or expanding entitlements. By contrast, it could be helpful when governments themselves elect to introduce measures to alleviate inequalities.

The main doctrinal justifications curtailing the Court's capacity to achieve redistributive justice through Charter litigations are policentricity, institutional competence, and budget constraints. Policentricity is synonymous with complex social policy issues (Alberta v Hutterian Brethren of Wilson Colony, [2009] 2 SCR 567, at paras. 35, 37, 53 and 56), and suggests caution in adjusting a measure as it is difficult to assess its impact in isolation. Put differently, since socio-economic measures are part of a broader network of actions, it is difficult to assess whether adjustments will result in an improvement in the enjoyment of rights or freedoms for the claimant or similarly situated persons (Wiseman 2015, p. 599). Institutional competence refers to judicial constraint in making complex policy choices. Ultimately, when claimants challenge a discriminatory underinclusiveness of programs, governments respond on automatic that budget constraints prevent them from expanding the eligibility/coverage of such programs. In this regard, a pattern was identified pointing to a wary attitude in extending programs that carry significant costs. By contrast, courts are more penchant to extending such programs where the cost of rights' recognition is low or null (Lessard 2012).

Hence, the notion of equality embraced by the Canadian equality jurisprudence is a relatively narrow one, due to its focus on rigid grounds of discrimination, an understanding of substantive equality as merely transformative (alongside with a reluctance to deliver it), a liberal understanding of constitutionalism that is in principle opposed to promoting redistributive justice, and, as a consequence, a host of selfimposed doctrinal justifications that the Court outlined to grant ample leeway to legislatures to make or otherwise social reforms.

Since it can be confidently inferred that equality is the key vehicle for "the transformation of power relationships and the redistribution of resources in our society" (McGill and Gilbert 2017, p. 257), I will now offer a critical review of the Canadian equality jurisprudence, seeking to outline its limits and trace its latent potential to address the ongoing exclusion of vulnerable groups.

\section{The Canadian model of constitutional review vis-à-vis discrimination}

At the constitutional level, Canada adopts an anti-discrimination approach to equality. The model presents the following features: a non-exhaustive list of protected grounds, which has been shaped and expanded over the time by the judiciary; a judicially mandated test for discrimination, which is unified in the sense that different grounds do not trigger different standards, as in the United States; a two-tier approach focused on the disadvantage suffered by a specific group, and on the absence of reasonable limits 
prescribed by law; and finally, a quite far-reaching protection, attentive not only to facially discriminatory rules, but also to the effects of facially neutral legislation (indirect discrimination). It is thus an open system, largely shaped by courts as for the protected grounds, relevant test, and type of the prohibited discrimination.

The relevant approach under section 15(1) is essentially two-pronged. First, the claimant must show a denial of "equal protection" or "equal benefit" of the law, as compared with some other group, and that the denial constitutes discrimination based on an enumerated or analogous ground (s. 15 or infringement prong). Once a violation is established, the onus shifts to the government to justify discrimination under s. 1 of the Charter (s. 1 or justification prong).

The interpretation of s. 15 has undergone a "winding course" ever since its inception (Hogg 2005, p. 41). The Court could not reach consensus over the interpretation of the clause and as a consequence the test kept changing and being adjusted almost every year. This inability to reach consensus contributed to shaping a non-linear test which clearly plays a role in discouraging equality claims altogether or nudging plaintiffs to go before human rights tribunals.

To oversimplify the winding course of the equality jurisprudence, one should especially recall the decision in Andrews, that established the two-pronged test and put forward a substantive vision of equality. Then came Law, which introduced a new analytical framework pivoting on human dignity (and requiring plaintiffs to further show that the law infringes on their dignity). Then, in 2008, Kapp reinstated a version of the Andrews approach, by requiring reviewing courts to answer whether (1) the law or government action creates a distinction based on a ground; and (2) the distinction is discriminatory, as it perpetuates prejudice or disadvantage. Yet another test was established under Quebec (Attorney General) v A, [2013] 1 SCR 61 [Quebec (AG) v A], and then adjusted in the recent companion decisions on Quebec's pay equity legislation (Quebec (Attorney General) v Alliance du personnel professionnel et technique de la santé et des services sociaux, [2018] 1 SCR 464 [APP]; Centrale des syndicats du Québec v Quebec (Attorney General), [2018] 1 SCR 522) [CSQ]. Under the current approach, courts are required to assess whether:

(1) the law or government action creates a distinction based on enumerated or analogous grounds; and

(2) the distinction reinforces, perpetuates, or exacerbates disadvantage.

I will give a cursory explanation of the scope of the second question of the infringement prong and then elaborate on the first question, concerning the need to link discriminatory actions to protected grounds, which is the focus of this paper.

The second question calls for an inquiry of the "arbitrary - or discriminatory disadvantage" and of "whether the impugned law fails to respond to the actual capacities and needs of the members of the group" (Kahkewistahaw First Nation v Taypotat, [2015] 2 SCR 548 [Taypotat], par. 19-20). The "arbitrary - or discriminatory disadvantage" it refers to requires a "flexible and contextual inquiry into whether a distinction has the effect of perpetuating arbitrary disadvantage on the claimant because of his or her membership in an enumerated or analogous group" (Quebec (AG) v A, par. 331). A treatment set forth by law is arbitrary or discriminatory if it does not correspond to the actual capacities of the members of the group and, conversely, withholds benefits 
thereby "reinforcing, perpetuating or exacerbating" a position of disadvantage (Taypotat, par. 19-20).

However, the Court has recently adjusted its approach in the two companion decisions on the Québec's pay equity legislation ( $A P P$ and $C S Q$ ). They both omitted any reference to the arbitrariness of the disadvantage and to the responsiveness to the capacities and needs of the members of the group. The second question is how does the law impose "burdens or denies a benefit in a manner that has the effect of reinforcing, perpetuating, or exacerbating (...) disadvantage (...)"? The Court in APP, par. 35 and CSQ, par. 22 merely added that disadvantage includes "historical" disadvantage. It is thus confirmed that disadvantage does not only mean prejudice or stereotyping. It is also confirmed that the issue is not one of causation nor intention of the legislature (CSQ, par. 35). Besides this, the Court did not elaborate on this second step and only its future application will enlighten its practical implications (Watson Hamilton 2018).

\subsection{Grounds}

At the time the Court started grappling with the equality clause, floodgates arguments ran against opening s. 15 to all legislative classifications and engendered a need to find a threshold barrier (Hogg 2005, p. 45). This is precisely the function that grounds assumed. The Court seemed to agree upon giving a primary role to grounds in defining the contours of constitutional litigation and of legal standing, unlike other systems where one could merely attack the arbitrariness of a treatment (as would be the case with systems adopting an equality approach or a rational basis test, such as that in force in the U.S., along with intermediate and strict scrutiny). Questions of reasonableness are dealt with under the s. 1 prong, where an inquiry of the reasonableness of the legislative distinction is conducted.

The text of s. 15 was conducive to arguing that grounds served as a threshold barrier: the fact that the equality guarantee listed some enumerated grounds, despite opening up the possibility of introducing new ones, suggested that s. 15 was not concerned with irrational classifications tout court but with classifications that unjustly discriminate against certain groups by reason of characteristics they possess.

Courts have been confronted with the question of interpreting grounds for discrimination ever since Andrews, the first equality challenge under the Charter. In Andrews, the top court inaugurated the mentioned "enumerated and analogous grounds approach", whereby it conferred upon grounds the function of screening out trivial claims (Andrews, par. 189). Thus, grounds soon become a threshold requirement to satisfy when seeking to enforce equality rights. The only member of the Court trying to reject this doctrine was L'Heureux-Dubé J, with her attempt to redirect focus onto an effect-based, contextualized inquiry over discrimination. Yet, no other justice engaged with this conversation, and she later joined the other members of the Court in Law in promoting a grounds-based approach to equality (Hogg 2005, p. 46).

This formalistic approach vis-à-vis the grounds of discrimination was never abandoned and continues to draw criticism from legal scholarship (Jackman 2010, p. 297, Eisen 2013). Legal scholars noted that, following Andrews, the majority of unsuccessful s. 15 claims failed precisely because claimant could not demonstrate discrimination linked to an enumerated or analogous ground (Ryder et al. 2004). Such a rigid categorical 
approach to equality had the practical implication of demanding that all groups plead their claims in terms of a violation of s. 15 based on one (or more) of the existing grounds. Yet, despite s. 15 barring a generalized inquiry over irrational classifications, the inclusion of "analogous grounds" opened up the possibility to expand the reach of s. 15 to new situations, not envisaged by the text of the clause.

An analogous ground is a characteristic that bears resemblance with the enumerated grounds in some important respect and that is unchangeable or can only be changed at excessive cost. Over the last thirty years, the Court laid out alternative approaches to determining whether an analogous ground is present:

(1) The target group constitutes a discrete and insular minority which lacks political power and does not fully participate in the political process (Andrews); (2) The target group suffers from historical disadvantage (Corbiere $v$ Canada (Minister of Indian and Northern Affairs), [1999] 2 SCR 203) [Corbiere]; (3) The distinction is grounded on a personal characteristic which is immutable (Andrews) or can only be changed at unacceptable personal expense (Miron v Trudel, [1995] 2 SCR 418) [Miron].

The current approach is that under (3). It was outlined in the Corbiere case, which linked the notion of analogous ground to the immutability or constructive immutability of the characteristic. Grounds thus became synonym at "characteristics that we cannot change or that the government has no legitimate interest in expecting us to change to receive equal treatment under the law" (Corbiere, par. 13). Under this approach, courts are called upon to assess whether a personal characteristic can only be changed at unacceptable personal expense. In the context of marital status discrimination, a similar catch 22 would occur if some couples were forced to change their status from "unmarried" to "married" to get some legal benefits.

In the first equality case addressing the issue of analogous grounds, the Court recognized non-citizenship (Andrews; Lavoie v Canada, [2002] 1 SCR 769). The only member of the Court trying to wrestle with a definition was La Forest J. In so doing, he emphasized that citizenship was immutable in the sense that it is a personal characteristic beyond an individual's control.

The second decision bearing on the issue of analogous grounds was Miron, where "marital status" was added to the list. As for the substantive outcome of the case, the Court concluded that, through the Insurance Act, R.S.O. 1980, c. 218, the Ontario legislature was not defining the content of relationships (something which would be legitimate), but unduly excluding common law spouses from the benefits under the automobile insurance plan. Common law spouses qualified under marital status as their relationship was seen a personal characteristic that can only be changed at unacceptable personal cost (so-called "constructive immutability"). While only four justices agreed that marital status qualified as an analogous ground, with L'Heureux-Dubé J discarding the issue as irrelevant, a unanimous Court later confirmed the inclusion of marital status within the list of protected grounds (Nova Scotia (Attorney General) $v$ Walsh, [2002] 4 SCR 325) [Walsh]. Then, in Walsh, despite reaching consensus on the issue of the inclusion of marital status, the Court did not uphold a claim that, by limiting the presumption of equal division of property to married couples, a Nova Scotia law discriminated on the basis of this ground. Pursuant to the reasoning of the Court, the Act was not biased against common law relationships but merely "defining the legal content of 
relationships and providing that any individuals in a conjugal relationship could, without changing their marital status, make a consensual choice to avail themselves of rights, obligations and restrictions analogous to the ones contained in the MPA [Marital Property Act]".

The Court later recognized sexual orientation, based on the immutability and constructive immutability doctrine (Egan; Vriend v Alberta, [1998] 1 SCR 493; Little Sisters Book and Art Emporium v Canada (Minister of Justice), [2000] 2 SCR 1120), and aboriginalityresidence (Corbiere) as analogous grounds. By contrast, the argument that place of residence is an analogous ground was not accepted (R. $v$ Turpin, [1989] 1 SCR 1296) [Turpin]. In Turpin, the two applicants, charged with murder, alleged a discriminatory treatment compared to residents of Alberta, for the Criminal Code did not allow them to opt for a trial by judge alone. The Court unanimously rejected their claim reasoning from the purpose of the section, which is that of preventing "discrimination against groups suffering social, political, and legal disadvantage in our society". It thus concluded that "residents outside Alberta" does not constitute an analogous ground (Macklem et al. 2016, p. 1290).

The occupational status saga is highly relevant to this analysis in that groups of workers lack a coherent identity and their mobilization is based on the material interest which is pursued. This bears resemblance with the host of new families that do not lay claim to an identity but merely seek legal protections in certain domains. However, the Court consistently declined to find that occupational status of farm workers is an analogous ground (Reference Re Workers' Compensation Act, 1983 (Nfld.), [1989] 1 SCR 922; Baier v Alberta, [2007] 2 SCR 673; Dunmore v Ontario (Attorney General), [2001] 3 SCR 1016). Yet, in Ontario (Attorney General) v Fraser, [2011] 2 SCR 3 [Fraser], a case concerning the protection of farm workers governed by a separate labor relations regime, it dismissed the s. 15 claim on the ground that there was an insufficient evidentiary record showing that the new law yielded an adverse impact on farm workers (instead of discarding it for inability to link discrimination to a prohibited ground) (Sheppard 2015, p. 225). By contrast, the concurring opinion of Justice Rothstein rejected the claim reasoning that employment status was not an analogous ground, as the plaintiff did not successfully establish that the regime "utilizes unfair stereotypes or perpetuates existing prejudice and disadvantage" (Fraser).

In addition to squaring up with grounds, claimants were required to "fall through the cracks" (Iyer 1993) once more by finding the appropriate comparator group. The locution refers to a group with which "the claimant shares the characteristics relevant to qualification for the benefit or burden in question, except for the personal characteristic that is said to be the ground of wrongful discrimination" (Hodge $v$ Canada (Minister of Human Resources Development), [2004] 3 SCR 357) [Hodge]. Dominant societal perceptions not only creep in when determining whether groups can successfully identify with a certain ground, but also at the later stage where claimants are assessed against the comparator group. For instance, in Hodge the claimant was a separated common law spouse. She was unable to get the survivor's pension available to separated (yet not divorced) married spouses. Her claim was rejected on the ground that the mirror comparator group was "former spouses", not legally separated spouses. In my view, the Court penalized her for not having entered into a lawful marriage, which is conceived 
as the paradigmatic family union. Since the relationship ended a few months before her partner's death, the Court considered her as a divorced, rather than separated, woman. Inexorably, if the unspoken background norm against which a common law couple is assessed is the marital family, the two common law spouses are doomed to be seen as deviant and unworthy of state support.

The recent move of the Court to do without a mirror comparator group is extremely beneficial (Withler $v$ Canada (Attorney General), [2011] 1 SCR 396), since the identification of such comparator groups was a place where equality claims were liable to founder (Pothier 2006, p. 149). As argued by the Court, "the focus on a precisely corresponding, or "like" comparator group, becomes a search for sameness, rather than a search for disadvantage, again occluding the real issue - whether the law disadvantages the claimant or perpetuates a stigmatized view of the claimant". This important decision avoids time-consuming searches for a group that resembles the applicants' one under some respects and reduces the risk that the application is rejected due to an impossibility to find the appropriate comparator.

\section{4. "Grounding" equality in the Constitution: Addressing old and new forms of exclusion}

It is worth recalling that ever since its first equality decision under the Charter, the Canadian Supreme Court resolved to adopt a grounds-based approach to equality, thereby putting a great deal of emphasis on the necessity to link the discrimination to certain characteristics, as opposed to the substantive outcomes of a legal regime on certain groups. The practical implication of this decision has been to compel people to comply with existing categories, when a proxy is available, as in the case of new family unions. A failure to do so would have entailed, as if often did, exclusion from the enjoyment of equality rights.

This Section attempts to imagine some hermeneutical routes to reach a notion of equality in constitutional pleadings that places emphasis on the redistributive dimension of equality and overcomes the problems associated with a "typical" (categorical) s. 15 pleading. I do not intend to argue that we should put aside grounds altogether. This would entail an overarching and undemonstrated claim that equality approaches are superior to grounds-based anti-discrimination approaches, which I think would be misplaced. I believe that the problem does not lie in grounds per se, but in the way courts use them to further a certain theory of justice.

A liberal and large interpretation of existing categories could in fact lead to meeting the needs of more fluid and cross-sectional groups, still disregarded by the law, with a view to ending the economic exclusion "perpetrated" by society and the state to the detriment of a subset of people excluded from "privileges and favors" (Fineman 2010-2011).

My case studies are new family unions, including both non-traditional conjugal families (such as polyamorous relationships), and non-conjugal families. The two routes I identify to promote a substantive notion of equality aiming at redistribution in the field of family law are the following:

(1) Keeping grounds and removing indicators;

(2) Keeping grounds and setting forth much less stringent indicators. 


\subsection{Keeping grounds and removing indicators}

A first proposal aimed at achieving a more liberal and large interpretation of "analogous grounds" keeps status (a synonym for "grounds") but broadens it significantly. The implied consequence of "broadening" the notion of status is to downplay its function as a threshold requirement. A liberal construction of analogous grounds can be obtained by removing "indicators" that are germane to a finding that a person belongs to the group. In this sense, any situation will require an analysis of its own, without the possibility of laying out a precise methodology. The insights of postmodernism, as is known, do not offer a settled methodology or agenda, but rather offer a new paradigm against which to assess current statuses (Freeman 1994, p. 80). In the field of family law, this translates into an approach that critiques the traditional and dominant understanding of family in selected sites of inquiries (i.e. with regard to specific benefits), without a need to make claims applicable across the board.

Absent a shift towards incorporating the post-structuralist insights of intersectionality and complex social identities, the current equality doctrine severely limits the chances of group outcasts to be protected. The case law on analogous grounds I have discussed previously.

The current approach, reinstated in Corbiere, is that under (3), which links the notion of analogous ground to the immutability (or constructive immutability) of the characteristic. As suggested by the intervenor LEAF, in the Andrews factum, analogous grounds refer to situations where there are similarities within the new group and enumerated groups, and the new group suffers from historical disadvantage on the basis of an immutable or constructively immutable characteristic (McGill and Gilbert 2017, p. 238). Emphasis is thereby placed on those who are "powerless, excluded and disadvantaged" within the broader seemingly neutral categories (Women's Legal Education and Action Fund - LEAF - 1989, paras. 23, 24, 33). The Court slowly drifted away from this approach, and accepted that, but for disability, other grounds should be protected symmetrically (i.e., men, despite lacking a history of discrimination and exclusion, could bring equality challenges just like women). Until 2003, the only equality judgment that reached unanimous consensus on the part of the Justices was indeed one that found in favor of a men in a sex discrimination challenge (Trociuk $v$ British Columbia (Attorney General), [2003] 1 SCR 835). This is precisely what in Section 2.1. I referred to as the paradigmatic "anomalous outcome" of current grounds-based approaches to equality.

I believe that there are two suitable approaches for broadening grounds without keeping indicators, in such a way that comports with the insights of anti-essentialism. The first approach is derived from the Equality for Gays and Lesbians Everywhere (EGALE) factum in Canada (Attorney General) v Mossop, [1993] 1 SCR 554 [Mossop]. The second approach is epitomized by the dissenting opinion of Justice L'Heureux-Dubé in Egan.

Mossop was a case decided by the Supreme Court in 1993. In Mossop, the claimant was a gay man lamenting an exclusion from the enjoyment of bereavement leave, an employment benefit. He argued that his partner's father, whose funeral he intended to attend, was "family" for purposes of the "family status" ground under the Canadian Human Rights Act, i.e. the federal human rights code. The coalition EGALE, in its intervenor factum, proposed an approach to defining family that was in sharp contrast 
with that of the appellant, the Canadian Human Rights Commission (CHRC). While the latter was arguing through a "sameness approach" that gay relationships were "just like" heterosexual relationships, EGALE insisted that family should be defined in an open-ended way or, in the alternative, that the family relationship qualification should be removed from the statute regulating bereavement leave.

This proposal was put forward in an attempt to acknowledge that social reality reflects an increasing diversity in family structures. Notwithstanding a steadfast evolution in family patterns, statistics are either unavailable or only partially capture such a diversity. Census data are based on traditional definitions of family and thus only capture a tiny portion of this multi-fold reality. In light of this reality, definitions attempting to incorporate a "core" of what family is are doomed to be unworkable (Freeman 1994, p. $50)$.

EGALE was eventually unsuccessful in its efforts to find a core: "Being anti-essentialist in this context meant refusing to use an abstract and universal definition intended to capture the 'essence' of family because it would be indefensibly reductive and exclude a variety of affiliations" (Freeman 1994, p. 63). The initial attempt of the coalition to find a viable indicator in "love" was later criticized by the coalition itself as factually inaccurate and too idealistic. Many partnerships are based on reasons other than love, such as companionship, or economic convenience. This point was recognized by the Supreme Court in Quebec $(A G) v A$., where Justice LeBel acknowledged that in the modern era, even marriage is not a union but a socio-economic partnership (para. 5). Furthermore, any alternative approach would have obtained recognition of the Mossop's family at the cost of entrenching exclusions for other groups unable to comply with the definition (think about a non-conjugal family, which does not conceive "love" in terms of a sexual, romantic relationship). By contrast, an open-ended definition, based on the subjective perception of who is family to us, is more coherent with the inclusive rather than exclusionary purpose of equality.

The factum highlighted that the definition of family need not be arbitrary and stressed that such a definition should be linked to the purpose of the benefit. If the purpose of the bereavement benefit is to allow a person to mourn someone she has a close connection with or to support a closely related person who mourns someone, then any principled restriction in the family relationship qualification is invidious. The final decision as to who is close enough to warrant mourning or support lies with the employee. Any objection vis-à-vis the cost of an unfettered expansion of the definition could be overcome by putting a cap on the number of hours one could claim.

In the end, this approach incorporates the tenets of anti-essentialism, by acknowledging that family can mean different things depending on the context, and that ever-shifting family patterns require a contextualized rather than static inquiry over the appropriate legal definitions "policing" access to certain benefits. EGALE's conception of family is more based on the normative principle of autonomy than on the notion of vulnerability. This normative justification is preferable if one considers that common law courts are more acquainted with autonomy-based arguments. However, they are quite unlikely to uphold such claims in the context of material benefits, due to the liberal understanding of constitutionalism discussed above. In such a context, autonomy is a weak normative basis on which compelling states to introduce new or expand existing legal entitlements. 
By contrast, vulnerability, with its focus on relational experiences and structures of domination, is a more solid normative foundation, conducive to arguing for a state duty in alleviating marginalization. Thus, the EGALE's approach, while highly respectful of the diversity of family structures, has a low likelihood of success in Canada.

A second approach conducive to broadening status (and removing indicators), which is more compatible with the normative principle of vulnerability, is that suggested by Justice L'Heureux-Dubé in Egan. The approach is a purposive human dignity one that seeks to inquire whether a person has been treated with equal concern, respect and consideration in our society. It takes socially vulnerable groups that suffered historical disadvantage as the privileged beneficiaries of equality challenges and minimizes the impact of grounds to the extent that they are no longer seen as a means to an end, but as markers conducive to detecting discrimination and unveiling power relationships (Gilbert 2003, p. 632). While at present a lot of ink is spilled to determine whether a claimant's experience can be linked to an enumerated or analogous grounds, she suggests that we stop using grounds as pre-conditions to a finding of discrimination and rather focus on the "effects" or "impact" of such discriminatory conduct on claimants (Egan, p. 549).

As argued, the trilogy of s. 15 decisions of 1995 (Egan, Miron; and Thibaudeau v Canada, [1995] 2 SCR [Thibaudeau]) was eager to abandon the previous disadvantage-based approach, to place greater emphasis on the grounds. Justice L'Heureux-Dubé was then the only member of the Court resisting the desertion of the group-disadvantage approach, by promoting a test that looks to groups rather than grounds. In Egan, she offered a manifesto of the approach:

As this Court has frequently acknowledged, the essence of discrimination is its impact, not its intention. The enumerated or analogous nature of a given ground should not be a necessary precondition to a finding of discrimination. If anything, a finding of discrimination is a precondition to the recognition of an analogous ground. The effect of the "enumerated or analogous grounds" approach may be to narrow the ambit of s. 15, and to encourage too much analysis at the wrong level (...).

To make matters worse, in defining the appropriate categories upon which findings of discrimination may be based, we risk relying on conventions and stereotypes about individuals within these categories that, themselves, further entrench a discriminatory status quo. More often than not, disadvantage arises from the way in which society treats particular individuals, rather than from any characteristic inherent in those individuals. (Egan, par. 551-52; emphasis added)

She expresses concern that by looking at the grounds instead of the impact of the distinction on specific groups the Court might end up distancing herself from the reality of persons' lives and experiences (Egan, par. 552). In so doing, she aptly stresses that disadvantage is much more likely to arise from the way in which individuals are treated, rather than from some characteristics one possesses (Egan, par. 552). Her approach is in the end more suitable to an analysis aimed at achieving redistributive justice for nontraditional families (and other vulnerable groups) in that it expressly focuses on economic prejudice and denial of benefits. 
A thus-framed analytical framework individualizes and contextualizes inquiries over discrimination since, in seeking to find whether the person belongs to a socially vulnerable group, it puts discrimination, not grounds, first. This is not to say that male claimants would never be able to bring an equality challenge, as an individualized noncategorical approach only entails that they can no longer do so based on a mere allegation that the ground of sex is involved. A quid pluris would be required, that is a proper showing that the claimant belongs to a subordinated group that is stripped of some assets, privileges and resources that other groups enjoy by virtue of the current allocation of these assets, privileges, and resources. While a context-sensitive inquiry will allow the male claimant to tell his personal experience of discrimination, a mere attempt to link discrimination to the ground of sex will no longer suffice, as any ground would be seen as an "imperfect vehicle" (Egan, p. 548). Prof. Gilbert aptly illustrates this point, by arguing that "[ $t]$ he enumerated grounds might be relevant in assessing the claimant and the court to identify a main characteristic of the group (...), but the focus is on identifying a group with whom the claimant shares a history of marginalization or social vulnerability" (Gilbert 2003, pp. 633-34).

Her approach, however, is not one that promotes the abolition of grounds. By contrast, it has the practical implication of enlarging the list of possible grounds (Pothier 1996, p. 316), while shifting the focus of the grounds analysis from one that takes them as preconditions to a finding of discrimination to one that first seeks to detect discrimination and then identifies the ground on which it occurs for "descriptive" purposes.

If one is to apply her approach to new families, new "analogous grounds" conducive to redistribution-oriented equality would be family status, non-conjugal family status or multi-generation family status. The order in which I place these terms is deliberate, as it goes from the broadest to the narrowest category. The list could continue by listing other sub-sets of affiliative relationships to the point that the category presents very little heuristic and descriptive value. Disclaimer: this is not a problem at all, if one follows anti-essentialist and post-structuralist accounts of social identity(ies). Allowing selfidentification with the group that better reflects one's personal experience, however narrow or multi-faceted the contours of the group are, is precisely the strength of this approach.

This point conjures up the notion of a "confluence of grounds" or "intersection of grounds" that the Supreme Court itself recognized as a possibility in equality litigation (Law, paras. 93 and 94). Under a thus-framed analytical framework, new groups based on a confluence of grounds would be acknowledged by introducing new analogous grounds that better reflect the reality of their complex position: domestic workers would be recognized and protected as such instead of shoehorning their identity into sex, race or both (Sheppard 2001, p. 914); custodial parents could constitute an analogous ground without a need to further inquire whether sex discrimination occurred (Thibaudeau, L'Heureux-Dubé and McLachlin JJ dissent; Pothier 1996, pp. 323-24); and a group of elderly claimants, mainly female widows, as the claimants in Whitler, could be considered as suffering discrimination based on a confluence of the grounds of age and sex. 
The Sparks decision by the Nova Scotia Court of Appeal anticipated this approach (Sparks $v$ Dartmouth/Halifax County Regional Housing Authority, 1993 CanLII 3176 (NS CA)) [Sparks]. The case scrutinized an allegation of discrimination against public housing tenants. It was argued on behalf of the claimants that adverse discrimination on grounds of race, sex, and income occurred given that low-income black women were disproportionately affected by the worst treatment public housing tenants endured under the law, compared to the treatment enjoyed by tenants of a private sector landlords (the "security of tenure" provision prevented the latter but not the former from being given short notice to quit the premises). Yet, the Court held that public housing tenants formed an analogous ground (Sparks, para. 33-34), and thus there was no need to force claimants to identify with the existing grounds of sex, race, and income to prove discrimination.

In Law, while the Court focused its analysis on the ground of age, Nancy Law, the claimant, would have been allowed to narrate her experience freely, with the possibility of bringing in factors crucial to her complex identity, such as the fact she was a woman, self-employed, and a young widow (Gilbert 2003, p. 635). In this sense, she would not have been required to "create" a group, but rather to recount all the relevant facets of her life germane to finding whether historical disadvantage (and discrimination) occurred.

Ironically, this approach has been criticized for carrying a risk of overcompartmentalization (Pothier 1996, p. 317). Returning to the example of domestic workers, according to Prof. Pothier, it is preferable to address the indirect discrimination of women, i.e. the adverse effect they suffer, rather than analyzing the direct effect on domestic workers. This would avoid "losing sight of the larger context" and "of the forest for the trees" (Pothier 1996, p. 317).

I cannot share this view. Her approach is only suitable whenever a claimant can somehow link her experience of discrimination to an existing ground. By contrast, the "analogous grounds" route, as understood by L'Heureux-Dubé J, is useful in expanding the reach of the equality clause to groups with complex identities, that can hardly align with rigid categories.

In the end, a liberal and large interpretation of analogous grounds that incorporates the insights of intersectionality is a suitable solution that opens up the "possibility of fluid, specific, and ever-changing categories that resonate with the complexity of multiple identities" (Sheppard 2001, p. 915). I see no reason for keeping the current focus on sex, race, sexual orientation, etc. when this entails exclusion of groups that, despite suffering disadvantage, do not align with these categories.

\subsection{Keeping status and much less stringent indicators}

Anti-essentialism is mostly compatible with avoiding indicators altogether. However, I intend to lay out a proposal that, while keeping indicators, loosens them to the point of reaching more inclusive outcomes. The approach that starts from certain typical features (or indicators) to detect whether two comparative elements can be analogized is called the "functional approach". In Canadian family law, a functional mechanism for recognizing common law marriages is in force, and goes by the name "ascription". Parties to a common law marriage, whether same-sex or opposite sex, enjoy some of the 
protections of marriage, mainly through an ascriptive regime at the federal and provincial level (in common law provinces), despite significant differences across provinces and across areas of regulation (Alberta Law Reform Institute 2018, para. 199).

Yet, in the field of family law, functionalist inquiries always tend to take the marital couple as the benchmark, hence the term "marital like relationships". For instance, in courts dealing with family matters the landmark precedent in clarifying the notion of marital-like relationship is Molodowich $v$ Penttinen (1980 CanLII 1537 (ON SC)). In the decision, the Court provided some useful guidance on how determining whether a consortium between the parties existed. It relied on the following functional characteristics, none of which had to be necessarily present, but all of which were considered in making the determination: shelter and sleeping arrangements, sexual and personal behavior (e.g. their attitude of fidelity), services (e.g. preparation of meals), social activities, societal attitude of the community toward the couple, economic support and financial arrangements, and children. Notwithstanding the clarification that no quality is necessary, the functional test has been criticized for comparing new family formations to an overly idealized notion of marital union, thereby making it harder for non-normative families to pass muster (Ontario Law Reform Commission 1993, p. 62).

Courts progressively realized the dangers associated with an "elusive quest for marriage equivalence" (Cossman and Ryder 2001, p. 314). The Supreme Court itself acknowledged that this aspirational model could be employed to subject non-traditional families to a higher scrutiny compared to families conforming to the traditional norm (Mossop, para. 638). An approach which is more contextual was thus embraced in Macmillan-Dekker v Dekker (2000 CanLII 22428 (ON SC)) [Macmillan-Dekker]. The Court thereto held that: "Each case must be examined in light of its own unique, objective facts (...) the seven [Molodowich] factors are meant to provide the Court with a flexible yet objective tool for examining the nature of relationships on a case-by-case basis" (Macmillan-Dekker, para. 68). No index is hence determinative and conclusive in isolation from the others.

Yet, however liberally construed, the dangers of this approach cannot be overstated. Let's consider the example of non-conjugal families. It is uncontroversial that marriage is unsuitable for non-conjugal couples. First, non-conjugal families are by no means interested in marriage and thus do not structure their relationship in such a way to fit the category. I would not want to marry my sister, while I would be willing to register her to assign some benefits (Williams 2016). Second, while marriage has now been made gender-neutral, it can hardly be disentangled from conjugality, exclusivity, and other constraining markers. Actually, not only can it hardly be disentangled from conjugality, but, due to marriage equality advocacy in Canada, the link between the two is also now stronger than ever (Cossman and Ryder 2017, p. 241).

This concern over the influence of conjugality can only be attenuated, yet not overcome, by the Supreme Court's decision to adopt a living tree principle in the interpretation of the meaning of marriage, "which, by way of progressive interpretation, accommodates and addresses the realities of modern life" (Reference Re: Marriage Act (Canada), 46 SCR, para. 22). This approach is open to any adjustment required by evolving notions of equality. It expressly refuses to rely on frozen concepts and to inquire over a purportedly "natural" meaning of marriage. Yet, the descriptive considerations around the fluidity, 
non-exclusivity, and structural non-heteronormativity of these families (Rosenbury 2007 , p. 231) suggest that non-conjugal families can hardly fit into marriage, no matter what liberal and large interpretation is given to its eligibility requirements.

Even if one were to remove conjugality as the central feature of familyhood, it is difficult to find viable indicators. Indicators that seem somehow less harmful to new families, such as shared residence or pooled finances, are not universal (Freeman 1994, p. 70, McGuire 2015).

However, a principled approach that addresses from scratch the functional attributes of familyhood could be somehow conducive to including rather than excluding nontraditional families.

It should not be neglected that some of the most important victories of common law couples or same-sex couples were obtained through a functional inquiry of their familyhood. In relying on the functional characteristic of the applicants, these decisions rejected the stereotypical view that they could not function as family. Under this reasoning, a denial of benefits could only be a consequence of merit or personal capability, not of wrongly attributed characteristics (Kapp, para. 18). In the recent case Quebec $(A G) v A$., the Court found the distinction between married and unmarried couples to be discriminatory upon finding (a) a history of exclusion from economic remedies, and (b) that de facto spouses in Quebec are functionally similar to married couples. Likewise, in M. v H. ([1999] 2 SCR 3) [M. v H.], the Supreme Court argued that the exclusion of same-sex partners "implies that they are judged to be incapable of forming intimate relationships of economic interdependence," and that "[b]eing in a same-sex relationship does not mean that it is an impermanent or a nonconjugal relationship" (M. v H., para. 151). Yet, it is problematic that the Court put language pointing to the relevance of sexual intimacy and to a presumed link between "impermanence" and "nonconjugality".

The problem is not necessarily the functional similarity prong per se, but the way in which it is understood and applied by courts. Needless to say, the "functional similarity" prong carries numerous risks. The need to choose the appropriate benchmark is crucial. If courts were to retain their focus on families that resemble the ideal marital couple, there would be no way forward for the recognition of new families. By contrast, if the law seeks to set forth less stringent indicators the prognosis can be more optimistic.

An example of a viable definition can be found in the U.S. case Braschi v Stahl Assocs. Co. (543 N.E.2d 49 (1989)). There, a New York court dealing with succession rights in a rentcontrolled apartment, construed the term "family" under the rent control code as encompassing family members who have not formalized their relationship. In assessing the objective of the law, the Court concluded that the intended protection against sudden eviction should not rest on legal fictions, such as a marriage certificate or an adoption order. The Court set forth several criteria to go beyond "fictitious legal distinctions" and account for the "reality of family life", amongst which were: "the exclusivity and longevity of the relationship, the level of emotional and financial commitment, the manner in which the parties have conducted their everyday lives and held themselves out to society, and the reliance placed upon one another for daily family services". However, while this definition seems to leave room for autonomy and choice in 
identifying the appropriate family member, the Court seemed unable to get rid of rigid marital-like indicators such as exclusivity, that do not necessarily apply to new families.

By contrast, the remaining indicators are more loose and open to self-authorship in defining family. The Law Commission of Canada, in its widely-cited report in 2001 Beyond Conjugality: Recognizing and Supporting Close Personal Adult Relationships, proposed to adopt "economic interdependency" and "emotional intimacy" as the litmus test to identity "family" across several contexts (Cossman and Ryder 2017). The report focused exclusively on non-conjugal caregiving. While acknowledging the limits of the methodological decision to leave out non-normative conjugal families, such as polyamorous relationships, the drafters were persuaded that it was premature to push for any reform in this sense. However, the two indicators outlined above could virtually apply to polyamorous relationships as well.

I wrestled myself with the issue of finding appropriate indicators. I came to the conclusion that a viable definition should only pivot on: (a) the consensual and horizontal nature of the relationship and (b) indicia of emotional and economic commitment, such as duration. The first criterion refers to the "free" decision of consenting adults to enter into the relationship, and therefore marks out the realm of horizontal relationships. It thus prevents a party from executing a formal relationship with a minor (so-called "vertical relationship"). Also, the condition is not met where there is a legal duty of support. For instance, parents still owing a duty of care to their children that come of age cannot be considered as parties to a horizontal relationship.

The second criterion refers to the seriousness of commitment. First, parties could prove that they are emotionally and economically committed by showing that the relationship is a long-standing one. While the creation of such commitment and the amount of time necessary to form it is highly subjective, proof that the relationship has unfolded over the time is a good starting point to detect commitment. Also, the Court could rely on alternative indicia of interdependency such as proof of income pooling or reciprocal emotional support. Ultimately, where available, a formal mechanism for recognition such as a registration scheme or contracts, would be the most viable mechanism to show that, by taking affirmative steps to self-designate a family member, one is emotionally and economically interdependent and thus merits state support.

In the end, while putting aside indicators altogether is the most immediate consequence of embracing a vision of equality that comports with redistributive justice and antiessentialist tenets, an attempt to reconcile indicators with this vision of equality can be made. However, if this route is chosen, one should select the indicators with the utmost care, to avoid the ever-present risk of essentialism.

\section{Are we ready to abandon identity in social activism?}

A grounds-based approach to discrimination directly impinges upon the organization of interest groups. Fixed categories, such as sex, race, and sexual orientation inevitably organize interest groups along identity lines for they are the principal "axes around which equality claims can be made" (Fineman 2008, pp. 2-3). Vice-versa, a different layout of interest groups aligning with post-structuralist accounts of identity is likely to put pressure on grounds-based antidiscrimination approaches to equality, as nowadays 
conceived. This is to say that there is a dynamic interplay between identity politics and grounds-based approaches to equality, with each reinforcing the other.

I have previously outlined the dangers of conceiving fixed identities. There are some additional specific dangers stemming from identity politics. For instance, born as a powerful tool to accommodate diversity, identity politics has now become a threat to pluralist democracy in so far as it injects an adversarial mindset into groups and unduly raises the stakes of victories/losses: "group conflicts [are] understood in often-bitter I win/you lose terms" (Eskridge 2002, pp. 2067-68). It also infuses losers with a dangerous feeling that the political system has disrespected their feelings and betrayed them. Chief amongst its pitfalls is its inability to challenge the systemic inequalities that derive from the way in which institutional arrangements confer assets only upon a sub-set of individuals. By contrast, a post-identity paradigm precisely intends to dismantle institutional systems that inflict disadvantage.

However, although I have attempted to offer in the previous two sections some solutions to reduce the dangers associated with a rigid grounds-based approach to equality, the question remains as to what form social activism should take in a post-identity politics world. The problem is that, while post-structuralist theories have long problematized those categories at the ontological and epistemological level, little scholarship has addressed the issues associated with social activism: that is, how individuals should group together (the coalescence problem) and how their agency should be framed (the agency problem) (Palazzo 2017). Fineman herself argued that "focusing on shared vulnerabilities and building a political movement around unequal institutional arrangements attendant to those vulnerabilities is a far more promising and powerful approach in addressing and correcting the disadvantage that persists in society." However, the question as to "how" these groups should gather and advocate for their interests is still relatively underdeveloped and much further analysis is needed.

I am thus engaging in the modest endeavor of laying the ground for a future conversation on the topic of how these new coalitions should group together and put forward their claims. The option that better comports with the vulnerability approach outlined in Section 2. is that of bringing together groups based on their interests or needs, rather than based on identity (and of dissolving them once the need is satisfied) (Fraser and Honneth 2003). An example of need/interest could be the obtainment of parental leave or the extension of the ability to inherit a share of the estate.

Such a proposal would yield many positive systemic effects such as reducing the social conflict associated with fixed identities. These groups would lack an adversarial mindset, as they would gather and dissolve upon fulfillment of their request. Thus, one could not fight against a group that she could potentially join. Furthermore, an interestbased action is more coherent with a "liquid" society, in which the demand for welfare services is increasingly particularized and in need of further articulation. It is thus more suitable to the structure of the modern welfare state.

Yet, if an interest-based approach is to be adopted, many questions remain open to debate. First and foremost, how framing the relevant need or interest. Is an environmentalist group or a specific class of workers (e.g., farmers) an interest-based group? Does their action aim at promoting material interests or a shared identity? The quality of "worker" is commonly understood as a status in civil law jurisdictions 
(Marella 2001, p. 32). Yet, as a status, it is fairly fluid, in the sense that membership in the group depends on characteristics which are not permanent, let alone immutable. Also, at the coalescence stage, the intention to advance a concrete interest seems to outweigh the defense of a shared identity (contrary to other groups, such as groups based on race, gender or sexual orientation). Likewise, within the broad category of non-normative families, non-conjugal families are mostly interested in gaining the material benefits of selective recognition, while polyamorous families are split between those arguing that the expressive benefits of promoting an identity are paramount and those mostly interested in gaining material benefits. The issue, therefore, pertains to all categories which lay at the boundaries of interest-based politics and identity politics. Where do we draw the line?

A second issue concerns whether there have already been groups which coalesced around interests in the past, and, if so, what their agency looked like. A viable example could be drawn from the so-called "AIDS activism". The label gathered a host of groups that fought to improve the life and treatment conditions of AIDS patients, in the period where the prevalence of the disease reached its peak (1980s), particularly in the United States. However, it has been demonstrated that identities, put aside at the coalescence stage, resurfaced at the agency stage. Especially, within the movement, black activists would fight for access to health care (as at the time they were largely excluded from it), while white activists for better treatment of AIDS patients. In a similar vein, the majority of women would oppose clinical trials of new drugs, while men would insist on including women as well in these trials (Stockdill 2001).

This is instructive of the fact that our societies cannot simply get rid of identities, as these identities are deeply rooted in our conscience. Even if overcome at the coalescence stage, they can always re-emerge. Therefore, it is integral to the success of post-identity platforms of social activism to have clearly stated objectives (i.e., a clear petitum).

Again, this is just a modest attempt to start a conversation, which is much needed. I contend that new groups which do not align with a fixed ground could put pressure on the current organization of interest groups and, by way of this, on the equality legal framework. Since social activism and equality legal frameworks stand in a relationship of reciprocal interference, it could either be the case that change starts from the law and then translates into social activism or vice-versa. Regardless of this chicken-or-egg question, if the prediction proves accurate, one should be well equipped first to understand social change, and second to accommodate it, by translating it into the legal and political domain.

\section{Concluding remarks}

The paper has explored a controversial topic which touches the heart of crucial issues, such as the ultimate purpose of equality and the connected role that states play in furthering this complex value into their social contract. The selected jurisdiction for conducting such an ambitious analysis, Canada, turned out the most appropriate starting point to address the dangers associated with a grounds-based approach to equality. The issue of grounds in Canada, while gaining greater momentum in the first two decades of Charter litigation under s. 15, have become less rampant in the last few years, as the grounds-based analysis became relatively settled. This is thus a modest 
contribution to re-open a much-needed debate as to whether rigid grounds can effectively disentangle discrimination.

Marital status discrimination seemed to be the perfect site of inquiry. While some of the proposals outlined in the article could aptly apply to other grounds (as the existence of group outcasts is not unique to the marital or family status ground), it seemed that family law held the greatest potential to unveil the "discrimination" the current antidiscrimination framework perpetrates against individuals unable to identify with the applicable grounds.

In light of this, I offered two set of proposals to inject (1) the post-structuralist insights of intersectionality and complex social identity and (2) the redistributive dimension of substantive equality into the current equality approach at the constitutional level. The first set of proposals would just do without indicators and stress the importance of defining family or marital status in such a way that comports with anti-essentialism. In this regard, I recalled the EGALE's approach in the Mossop factum, pursuant to which family lacks a core definition and its meaning can only be appreciated in the context of the benefit that claimants seek to obtain. While welcoming such an approach as injecting a radical change into the current traditional model of family, I pointed to the limits of an autonomy-based notion of equality in the context of affirmative entitlements. I then outlined Justice L'Heureux-Dubé's approach in Egan, that would have merely allowed each and any claimant to tell his story of discrimination and identify with the category that better comports with her position, thereby downplaying the role of grounds from a normative to a descriptive one. This approach appeared to be more compatible with vulnerability as the key normative foundation to seek equality at the constitutional level in that it directly challenges the liberal understanding of constitutionalism and the doctrinal limits it places on positive duties on the part of public authorities.

A second set of proposals suggests keeping both grounds and indicators, while making indicators much less stringent. An example of viable indicators in the field of family law would be economic interdependency and emotional intimacy, as suggested by the Law Commission of Canada, or the consensual and horizontal nature of the relationship, and proof of commitment, as suggested by myself.

A final question concerned the organization of interest groups in a society that embraces the demise of monolithic identities, i.e., the issue of social activism. The underlying assumption was that approaches to equality and the layout of interest groups reinforce one another. Hence, an analysis of the legal system could not simply overlook how a different approach to equality would impact on social activism, and vice-versa. Yet, the issue of social activism is relatively underdeveloped in socio-legal scholarship. While stopping short of offering a complete overview of how groups do or should organize in a post-identity society, the paper described some of the problems researchers will need to grapple with in the near future.

The most important lesson I have learned from queer theory and other post-structuralist theories is that the neutrality of categories is just wishful thinking, and that the more the claimed neutrality the wider the impact on group outcasts which suffer from material and relational disadvantage. There is no such thing as "normality" or "deviance", despite our societies being obsessed with both. 
Scaling down notions of normality and deviance is the first essential stepping-stone to a reassessment of current anti-discrimination systems adopting a grounds-based approach to equality. Grounds are not detrimental per se, our seemingly neutral categorizations can be, if the background norms remain unspoken. The article is thus a modest attempt to outline the domino effect triggered by rethinking the aims of the principle of equality on anti-discrimination legal systems and interest groups, an effect which is much needed if one wants to embrace a vision of equality that fosters inclusion rather than exclusion.

\section{References}

Alberta Law Reform Institute, 2018. Property Division: Common Law Couples and Adult Interdependent Partners. Final Report 112. Alberta Law Reform Institute.

Appiah, A., 1992. In my Father's House: Africa in the Philosophy of Culture. London: Methuen.

Arthurs, H., and Arnold, B., 2005. Does the Charter Matter? Review of Constitutional Studies [online], 11(1), 37-117. Available from:

https:/pdfs.semanticscholar.org/3012/f6d13e698dc467af46e2461a98559df33247.pd f [Accessed 19 July 2019].

Battams, N., 2018. A Snapshot of Family Diversity in Canada [online]. Ottawa: Statistical Snapshots. The Vanier Institute of the Family, February. Available from: https://vanierinstitute.ca/snapshot-family-diversity-canada-february-2018/ [Accessed 22 July 2019].

Boyd, J.P., 2017. Polyamory in Canada: Research on an Emerging Family Structure [online]. Ottawa: The Vanier Institute of the Family, April. Available from: https://vanierinstitute.ca/polyamory-in-canada-research-on-an-emerging-familystructure/ [Accessed 22 July 2019].

Bridgeman, J., 2013. Relational Vulnerability, Care and Dependency. In: J. Wallbank and J. Herring, eds., Vulnerabilities, Care and Family Law. Abingdon: Routledge.

British Columbia Law Institute, 1998. Report on Recognition of Spousal and Family Status [online]. Vancouver: British Columbia Law Institute. Available from: http://www.bcli.org/sites/default/files/5-Report-

Report on Recognition of Spousal and Family Support.pdf [Accessed 22 July 2019].

Butler, J., 1990. Gender Trouble. Abingdon: Routledge.

Cossman, B., and Fudge, J., eds., 2002. Privatization, Law and the Challenge to Feminism [online]. University of Toronto Press. Available from: https://doi.org/10.3138/9781442678774 [Accessed 22 July 2019].

Cossman, B., and Ryder, B., 2001. What is Marriage-Like Like? The Irrelevance of Conjugality. Canadian Journal of Family Law [online], 18(2), 269-326. Available from:

https://digitalcommons.osgoode.yorku.ca/cgi/viewcontent.cgi?referer=https://ww w.google.com $/ \&$ httpsredir $=1 \&$ article $=2376 \&$ context $=$ scholarly works [Accessed 22 July 2019]. 
Cossman, B., and Ryder, B., 2017. Beyond "Beyond Conjugality". Canadian Journal of Family Law [online], 30(2), 227-263. Available from:

https://ssrn.com/abstract=3111872 [Accessed 22 July 2019].

Eisen, J., 2013. On Shaky Grounds: Poverty and Analogous Grounds under the Charter. Canadian Journal of Poverty Law, 2(2), 1-33.

Eskridge, W., 2002. Some Effects of Identity-Based Social Movements on Constitutional Law in the Twentieth Century. Michigan Law Review [online], 100, 2063-2184.

Available from: https://digitalcommons.law.yale.edu/fss papers/3767 [Accessed 22 July 2019].

Faraday, F., Denike, M., and Stephenson, M.K., eds., 2006. Making Equality Rights Real: Securing Substantive Equality under the Charter. Toronto: Irwin Law.

Fineman, M.A., 2008. The Vulnerable Subject: Anchoring Equality in the Human Condition. Yale Journal of Law \& Feminism [online], 20(1), 1-23. Available from: http://digitalcommons.law.yale.edu/yjlf/vol20/iss1/2 [Accessed 22 July 2019].

Fineman, M.A., 2010-2011. The Vulnerable Subject and the Responsive State. Emory Law Journal [online], vol. 60, 251-275. Available from:

http://law.emory.edu/elj/ documents/volumes/60/2/symposium/fineman.pdf [Accessed 22 July 2019].

Fineman, M.A., 2012. "Elderly" as Vulnerable: Rethinking the Nature of Individual and Societal Responsibility. The Elder Law Journal [online], 20(2), 71-112. Available from: https://doi.org/10.2139/ssrn.2088159 [Accessed 22 July 2019].

Fraser, N., and Honneth, A., 2003. Redistribution or Recognition? A Political-Philosophical Exchange. London: Verso.

Fredman, S., 2011. Discrimination Law. $2^{\text {nd }}$ ed. Oxford University Press.

Fredman, S., 2012. Comparative study of anti-discrimination and equality laws of the US, Canada, South Africa and India [online]. Commissioned by the Directorate-General for Justice and Consumers (European Commission) and the European Network of Legal Experts in the Non-Discrimination Field. 14 November. Luxembourg: Office for Official Publications of the European Communities. Available from: https:/publications.europa.eu/en/publication-detail/-/publication/014f442a-abe34dfd-b688-43cda49c15db [Accessed 22 July 2019].

Freeman, J., 1994. Defining Family in Mossop v DSS: The Challenge of AntiEssentialism and Interactive Discrimination for Human Rights Litigation. The University of Toronto Law Journal [online], 44(1), 41-96. Available from: https://doi.org/10.2307/825754 [Accessed 22 July 2019].

Froc, K.A., 2011. Constitutional Coalescence: Substantive Equality as a Principle of Fundamental Justice. Ottawa Law Review [online], 42(3), 411-445. Available from: https://rdo-olr.org/en/2011/constitutional-coalescence-substantive-equality-as-aprinciple-of-fundamental-justice/ [Accessed 22 July 2019].

Gilbert, D., 2003. Time to Regroup: Rethinking Section 15 of the Charter. McGill Law Journal, 48(4), 627-649. 
Hameed, Y., and Simmonds, N., 2008. The Charter, Poverty Rights and the Space Between: Exploring Social Movements as a Forum for Advancing Social and Economic Rights in Canada. National Journal of Constitutional Law, 23(1), 181-213.

Herring, J., 2015. Vulnerable Adults and the Law [online]. Oxford University Press. Available from: https://doi.org/10.1093/acprof:oso/9780198737278.001.0001 [Accessed 22 July 2019].

Hogg, P.W., 2005. What is Equality?: The Winding Course of Judicial Interpretation. The Supreme Court Law Review [online], 29(2d), 39-62. Available from: http://digitalcommons.osgoode.yorku.ca/sclr/vol29/iss1/4 [Accessed 22 July 2019].

Iyer, N., 1993. Categorical Denials: Equality Rights and the Shaping of Social Identity. Queen's Law Journal, 19(1), 179-207.

Jackman, M., 2010. Constitutional Castaways: Poverty and the McLachlin Court. In: S. McIntyre and S. Rodgers, eds., The Supreme Court of Canada and Social Justice: Commitment, Retrenchment or Retreat. Toronto: LexisNexis Canada.

Jackman, M., and Porter, B., eds., 2014. Advancing Social Rights in Canada. Toronto: Irwin Law.

Kosofsky Sedgwick, E., 1990. Epistemology of the Closet. Upper Saddle River: PrenticeHall.

Law Commission of Canada, 2001. Beyond Conjugality: Recognizing and Supporting Close Adult Relationships [online]. Law Commission of Canada. Available from: https://ssrn.com/abstract=1720747 [Accessed 22 July 2019].

Le Bourdais, C., and Lapierre-Adamcyk, E., 2008. Portrait des familles québécoises à l'horizon 2020: esquisse des grandes tendances démographiques. In: G. Pronovost, C. Dumont and I. Bitaudeau (with E. Coutu), eds., La famille à l'horizon 2020. Presses de l'Université du Québec.

Leckey, R., 2007. Family Law as Fundamental Private Law. The Canadian Bar Review [online], 86, 69-96. Available from:

https://www.mcgill.ca/law/files/law/leckey family law fundamental private la w 2007.pdf [Accessed 22 July 2019].

Lessard, H., 2012. "Dollars Versus [Equality] Rights": Money and the Limits on Distributive Justice. The Supreme Court Law Review [online], 58(2d), 299-332. Available from: https://digitalcommons.osgoode.yorku.ca/sclr/vol58/iss1/11/ [Accessed 22 July 2019].

L'Heureux-Dubé, C., 2002. It Takes a Vision: The Constitutionalization of Equality in Canada. Yale Journal of Law \& Feminism [online], 14(2), 363-375. Available from: https://digitalcommons.law.yale.edu/yjlf/vol14/iss2/15/ [Accessed 22 July 2019].

Mackenzie, C., Rogers, W., and Dodds, S., eds., 2014. Vulnerability: New Essays in Ethics and Feminist Philosophy [online]. Oxford University Press. Available from: https://doi.org/10.1093/acprof:oso/9780199316649.001.0001 [Accessed 22 July 2019]. 
MacKinnon, C., 1987. Feminism Unmodified: Discourses on Life and Law [online]. Cambridge, MA: Harvard University Press. Available from: https://doi.org/10.2307/2070528 [Accessed 22 July 2019].

Macklem, P., et al., 2016. Canadian Consitutional Law. $5^{\text {th }}$ ed. Toronto: Emond.

Marella, M.R., 2001. Il diritto di famiglia tra status e contratto. In: F. Grillini and M.R. Marella, eds., Stare insieme: I regimi giuridici della convivenza tra status e contratto. Naples: Jovene.

McGill, J., and Gilbert, D., 2017. Of Promise and Peril: The Court and Equality Rights. The Supreme Court Law Review [online], 78(2d), 235-257. Available from: http://nawl.ca/pdf/ch10_gilbert_and_jena_edited_copy.pdf [Accessed 22 July 2019].

McGuire, A., 2015. The Case for Merging Finances in Marriage. Institute for Family Studies [online], 26 May. Blog post. Available from: https://ifstudies.org/blog/thecase-for-merging-finances-in-marriage [Accessed 20 May 2019].

McIntyre, S., and Rodgers, S., eds., 2006. Diminishing Returns: Inequality and the Canadian Charter of Rights and Freedoms. Toronto: LexisNexis Canada.

Ontario Law Reform Commission, 1993. Report on the Rights and Responsibilities of Cohabitants [online]. Toronto: Ontario Law Reform Commission. Available from: https://archive.org/details/esreportonrights00onta/page/n0 [Accessed 20 May 2019].

Palazzo, N., 2017. Identity politics e il suo reciproco: riflessioni giuridico-politiche sull'attivismo queer. In: A. Murgia and B. Poggio, eds., Prospettive interdisciplinari su formazione, università, lavoro, politiche e movimenti social [online]. Università degli Studi di Trento. Available from:

https://www.unitn.it/archivio/events/sites/events.unitn.it/files/saperidigeneredue 1.pdf [Accessed 20 July 2019].

Palazzo, N., 2018. The Strange Pairing: Building Alliances to Recognize New Families. Michigan Journal of Gender and Law [online], 25(2), 161-237. Available from: https://ssrn.com/abstract=3231913 [Accessed 20 July 2019].

Payne, J.D., and Payne, M.A., 2015. Canadian Family Law. $6^{\text {th }}$ ed. Toronto: Irwin Law.

Pothier, D., 1996. M'aider, Mayday: Section 15 of the Charter in Distress. National Journal of Constitutional Law, 6, 296-345.

Pothier, D., 2006. Equality as a Comparative Concept: Mirror, Mirror, on the Wall, What's the Fairest of Them All? The Supreme Court Law Review [online], 33(2d), 135-150. Available from: https://ssrn.com/abstract=2135156 [Accessed 22 July 2019].

Rosenbury, L.A., 2007. Friends with Benefits? Michigan Law Review [online], 106(2), 189242. Available from: http://repository.law.umich.edu/mlr/vol106/iss2/1 [Accessed 22 July 2019].

Ryder, B., 2013. The Strange Double Life of Canadian Equality Rights. The Supreme Court Law Review [online], 62(2d), 261-294. Available from: 
https://digitalcommons.osgoode.yorku.ca/sclr/vol63/iss1/11/ [Accessed 22 July 2019].

Ryder, B., Cidalia, C., and Lawrence, E., 2004. What's Law Good for? An Empirical Overview of Charter Equality Rights Decisions. The Supreme Court Law Review [online], 24(2d), 103. Available from:

https://digitalcommons.osgoode.yorku.ca/sclr/vol24/iss1/5 [Accessed 22 July 2019].

Sheppard, C., 2001. Grounds of Discrimination: Towards and Inclusive and Contextual Approach. The Canadian Bar Review [online], 80, 893-916. Available from: https://cbr.cba.org/index.php/cbr/article/download/3926/3919 [Accessed 22 July 2019].

Sheppard, C., 2015. “Bread and Roses": Economic Justice and Constitutional Rights. Oñati Socio-Legal Series [online], 5(1), 225-245. Available from: http://opo.iisj.net/index.php/osls/article/view/439/561 [Accessed 22 July 2019].

Stockdill, B.C., 2001. Forging a multidimensional oppositional consciousness: lessons from community-based AIDS activism. In: J. Mansbridge and A. Morris, eds., Oppositional Consciousness: The Subjective Toots of Social Protest. University of Chicago Press, 204-237.

Taylor, M.J., 1993. Queer Things from Old Closets: Libraries - Gay and Lesbian Studies - Queer Theory. Rare Books and Manuscripts Librarianship [online], 8(21). Available from: https://rbml.acrl.org/index.php/rbml/article/viewFile/93/93 [Accessed 22 July 2019].

Watson Hamilton, J., 2018. The Supreme Court of Canada's Approach to the Charter's Equality Guarantee in its Pay Equity Decisions. ABlawg.ca [online], 12 July. Available from: https://ablawg.ca/2018/07/12/the-supreme-court-of-canadasapproach-to-the-charters-equality-guarantee-in-its-pay-equity-decisions/ [Accessed 20 May 2019].

Williams, C., 2016. Nova Scotia sisters who've lived together 38 years want survivor benefits. $C B C$ [online], 28 October. Available from:

http://www.cbc.ca/news/canada/nova-scotia/nova-scotia-sisters-living-togetherbenefits-pension-access-1.3826095 [Accessed 22 July 2019].

Wiseman, D., 2015. The Past and Future of Constitutional Law and Social Justice: Majestic or Substantive Equality? The Supreme Court Law Review [online], 71(2d), 563-605. Available from: http://digitalcommons.osgoode.yorku.ca/sclr/vol71/iss1/22 [Accessed 22 July 2019].

Women's Legal Education and Action Fund (LEAF), 1989. Intervenor factum in Andrews $v$ Law Society of British Columbia, [1989] 1 SCR 143.

Young, I.M., 1990. Justice and the Politics of Difference. Princeton University Press.

Young, M., 2010. Unequal to the Task: 'Kapp'ing the Substantial Potential of Section 15. The Supreme Court Law Review [online], 50(2d), 183-219. Available from: https://commons.allard.ubc.ca/fac pubs/352/ [Accessed 22 July 2019]. 
Young, M., 2011. Why Rights Now? Law and Desperation. In: M. Young et al., eds., Poverty: Rights, Social Citizenship, and Legal Activism. Vancouver: University of British Columbia Press, 317-336.

Case law

Alberta v Hutterian Brethren of Wilson Colony, [2009] 2 SCR 567.

Andrews $v$ Law Society of British Columbia, [1989] 1 SCR 143.

Baier v Alberta, [2007] 2 SCR 673.

Braschi v Stahl Assocs. Co., 543 N.E.2d 49 (1989).

Canada (Attorney General) v Mossop, [1993] 1 SCR 554.

Centrale des syndicats du Québec v Quebec (Attorney General), [2018] 1 SCR 522.

Corbiere v Canada (Minister of Indian and Northern Affairs), [1999] 2 SCR 203.

Dunmore v Ontario (Attorney General), [2001] 3 SCR 1016.

Egan v Canada, [1995] 2 SCR 513.

Hodge v Canada (Minister of Human Resources Development), [2004] 3 SCR 357.

Kahkewistahaw First Nation v Taypotat, [2015] 2 SCR 548.

Lavoie v Canada, [2002] 1 SCR 769.

Law v Canada (Minister of Employment and Immigration), [1999] 1 SCR 497.

Little Sisters Book and Art Emporium v Canada (Minister of Justice), [2000] 2 SCR 1120.

M. $v$ H., [1999] 2 SCR 3.

Macmillan-Dekker v Dekker, 2000 CanLII 22428 (ON SC).

Miron v Trudel, [1995] 2 SCR 418.

Molodowich v Penttinen, 1980 CanLII 1537 (ON SC).

Nova Scotia (Attorney General) v Walsh, [2002] 4 SCR 325.

Ontario (Attorney General) v Fraser, [2011] 2 SCR 3.

Quebec (Attorney General) v A., [2013] 1 SCR 61.

Quebec (Attorney General) v Alliance du personnel professionnel et technique de la santé et des services sociaux, [2018] 1 SCR 464.

R. v Kapp, [2008] 2 SCR 483.

R. $v$ Turpin, [1989] 1 SCR 1296.

Reference Re: Marriage Act (Canada), 46 SCR.

Reference Re Workers' Compensation Act, 1983 (Nfld.), [1989] 1 SCR 922.

Sparks v Dartmouth/Halifax County Regional Housing Authority, 1993 CanLII 3176 (NS CA).

Thibaudeau v Canada, [1995] 2 SCR 627. 
Trociuk v British Columbia (Attorney General), [2003] 1 SCR 835.

Withler v Canada (Attorney General), [2011] 1 SCR 396.

Vriend v Alberta, [1998] 1 SCR 493. 